\title{
Do genetic factors contribute to the association between birth weight and blood pressure?
}

\author{
K Christensen, H Støvring, M McGue
}

\begin{abstract}
Objectives-To evaluate whether genetic factors contribute to the association between low birth weight and increased blood pressure among adolescents.

Design-Historical cohort study of twin pairs. It was evaluated whether (1) a negative association between birth weight and systolic blood pressure was found in the overall twin sample and (2) whether the intrapair difference in birth weight correlated with the intrapair difference in systolic blood pressure-thereby controlling for the effect of genetic factors (all in monozygotic and on average half in dizygotic pairs).
\end{abstract}

Setting-The Minnesota Twin Family Study.

Participants-1311 pairs of adolescent twins.

Main results-A negative association between birth weight and systolic blood pressure was retrieved in the overall sample. The regression coefficient after controlling for current weight was $-1.88 \mathbf{~ m m}$ $\mathrm{Hg} / \mathrm{kg}$ (SE 0.61), which corresponds to results from previous studies of singleton adolescents. The regression coefficient fell to $-0.64 \mathrm{~mm} \mathrm{Hg} / \mathrm{kg}$ (SE 0.86) when the intrapair analyses were used. The largest reduction was observed among monozygotic twins: from $-2.44 \mathrm{~mm} \mathrm{Hg} / \mathrm{kg}$ (SE 0.75 ) in the overall monozygotic twin sample to $-1.06 \mathrm{~mm} \mathrm{Hg} / \mathrm{kg}$ (SE 1.14) in the analyses of the within monozygotic pair differences.

Institute of Public Health, Epidemiology, and Institute for Demography and Statistics, University of Southern Denmark, Odense, Denmark K Christensen

H Støvring

Department of Psychology, University of Minnesota, Minneapolis, USA M McGue

Correspondence to: Dr Christensen, Institute of Public Health

(Epidemiology), University of Southern Denmark, Sd Boulevard 23A, DK-5000 Odense C, Denmark (KChristensen@) health.sdu.dk)

Accepted for publication 12 March 2001
Conclusion-The association between low birth weight and increased blood pressure later in life is well established. "The fetal programming hypothesis" suggests that the association is caused by intrauterine malnutrition while a new hypothesis "the fetal insulin hypothesis" proposes that genetically determined insulin resistance also contributes significantly to the association. A recent twin study of middle aged twins showed no evidence for an influence of genetic factors while this larger study provides support for the fetal insulin hypothesis: the association between birth weight and blood pressure attenuated among adolescents when genetic factors were controlled. Together this suggests an important contribution of genetic factors to the association between fetal growth and systolic blood pressure in adolescence.

(F Epidemiol Community Health 2001;55:583-587)
The association between low birth weight and later life insulin resistance, non-insulin dependent diabetes (NIDDM), coronary artery disease and hypertension has been confirmed in numerous studies. ${ }^{1}$ The fetal programming hypothesis suggests that a person's nourishment before birth "programmes" the development of risk factors for these diseases later in life. Within the past years two books have been published that review the literature pertinent to this hypothesis. In one of the books, Barker concludes that "Because of poor nutrition and health among girls and women, before and during pregnancy, many fetuses are undernourished. This permanently changes their structure, physiology and metabolism in ways that lead to chronic diseases in later life" ${ }^{1}$ (page 224). In contrast, Susser states in the foreword to the other book that "At best, if not unimportantly, programming could create predispositions and vulnerability to life course experience" (page vii).

There is little doubt that an association exists between fetal growth and later life health outcomes such as blood pressure or cardiovascular mortality. The key question is, however, whether it is fetal nourishment or other factors such as genes or socioeconomic conditions that cause the associations. Recent studies suggest that socioeconomic confounding cannot explain the association between fetal growth and cardiovascular mortality, ${ }^{3}$ but few studies have evaluated the influence of genetic confounding.

The potential for genetic confounding has been illustrated by Dunger et $a l,{ }^{4}$ who showed that variation in the insulin gene (INS VNTR) is associated with fetal growth. Based on studies of fetal insulin secretion and monogenic diseases, Hattersley and Tooke ${ }^{5}$ recently proposed that genetically determined insulin resistance contributes substantially to the association of low birth weight with diabetes, hypertension and vascular diseases and named this hypothesis the "fetal insulin hypothesis".

We used the Minnesota Twin Family study to test the potential influence of genetic confounding on the association between birth weight and systolic blood pressure, which is the best documented association between fetal growth and later life health outcome. ${ }^{126-8}$ The effect of genetic confounding was evaluated by analysing individual twin data as well as intrapair differences in birth weight and systolic blood pressure. This approach enables controlling for the effect of all genetic factors in monozygotic pairs and on average half of the genetic factors in dizygotic pairs as well as environmental maternal effects. Two recent 
Table 1 Sample characteristics according to sex, age and zygosity

\begin{tabular}{|c|c|c|c|c|c|c|c|c|c|}
\hline & \multirow[b]{3}{*}{ Age } & \multicolumn{4}{|c|}{ Monozygotic twins } & \multicolumn{4}{|c|}{ Dizygotic twins } \\
\hline & & \multirow[b]{2}{*}{ Number } & $\begin{array}{l}\text { Systolic blood } \\
\text { pressure }(\mathrm{mm} \mathrm{Hg})\end{array}$ & $\begin{array}{l}\text { Birth weight } \\
\text { (kg) }\end{array}$ & $\begin{array}{l}\text { Current weight } \\
(\mathrm{kg})\end{array}$ & \multirow[b]{2}{*}{ Number } & $\begin{array}{l}\text { Systolic blood } \\
\text { pressure }(\mathrm{mm} \mathrm{Hg})\end{array}$ & $\begin{array}{l}\text { Birth weight } \\
\text { (kg) }\end{array}$ & $\begin{array}{l}\text { Current weight } \\
(\mathrm{kg})\end{array}$ \\
\hline & & & \multicolumn{3}{|l|}{ Mean (SE) } & & \multicolumn{3}{|l|}{ Mean (SE) } \\
\hline \multirow[t]{2}{*}{ Male } & $11-12$ & 498 & $103.7(0.5)$ & $2.58(0.03)$ & $40.7(0.4)$ & 234 & $105.3(0.8)$ & $2.60(0.04)$ & $42.8(0.7)$ \\
\hline & $17-18$ & 368 & $118.6(0.6)$ & $2.60(0.03)$ & $71.1(0.6)$ & 194 & $119.3(0.9)$ & $2.79(0.03)$ & $73.6(0.9)$ \\
\hline \multirow[t]{2}{*}{ Female } & $11-12$ & 436 & $96.3(0.7)$ & $2.53(0.03)$ & $44.1(0.5)$ & 266 & $93.8(1.0)$ & $2.66(0.03)$ & $45.6(0.7)$ \\
\hline & $17-18$ & 420 & $103.2(0.7)$ & $2.61(0.03)$ & $60.8(0.5)$ & 206 & $102.3(0.9)$ & $2.55(0.04)$ & $62.5(0.9)$ \\
\hline
\end{tabular}

twin studies ${ }^{9}{ }^{10}$ using a similar design did not find evidence for a genetic component to the association, but as pointed out in the accompanying editorial, ${ }^{11}$ the number of monozygotic twin pairs in these studies was sparse.

Phillips $^{12}$ has argued that even small birth weight differences in twins could reflect important differences in intrauterine conditions important for programming of diseases later in life, because the mean birth weight among twins is already considerably lower than in singletons. Therefore, birth weight differences in twins offer a unique opportunity to test the "fetal insulin hypothesis".

\section{Methods}

PARTICIPANTS

The sample consisted of adolescent twin participants from the Minnesota Twin Family Study. Two cohorts were assessed: an 11 year old cohort assessed when the twins were approximately 11 years old (the age range is 11 to 12 years), and a 17 year old cohort assessed when the twins were approximately 17 years old (age range 17 to 18 years). The Minnesota Twin Family Study uses a population-based ascertainment scheme, with non-participating families differing minimally from participating families with respect to indicators of socioeconomic status and self reported mental health. ${ }^{13}$ Of the 1383 twin pairs who completed the Minnesota Twin Family Study intake assessment, the present sample consisted of the 1311 twin pairs with both members having a valid measurement of systolic blood pressure and birth weight. The major reasons for missing data were either the failure to record birth weight on the birth record, or the failure to measure blood pressure because the assessment day for some participants ran longer than the eight hour limit.

\section{MEASUREMENTS}

Three blood pressure readings were taken on each participant using an automated blood pressure recording system. Readings were obtained following standard procedures while the participant was sitting with their arm resting on a table. The median systolic recordings are analysed in this study. To adjust for possible calibration errors that might have occurred with the automated system over time, median blood pressure recordings were adjusted for the month in which it was taken. Specifically, for each month a five month running average was computed and subtracted from the overall mean. These mean deviations were subtracted from the observed median reading to produce an adjusted score. The adjustment of the blood pressure data had minimal impact on the values analysed. There was a slight, albeit statistically significant, tendency for blood pressure recordings to decrease over the course of the study. The adjusted scores differed on average by $2.5 \mathrm{~mm} \mathrm{Hg}$ in systolic blood pressure and $1.8 \mathrm{~mm} \mathrm{Hg}$ for diastolic blood pressure. Fewer than 3\% of the scores changed by as much as $8 \mathrm{~mm} \mathrm{Hg}$ systolic blood pressure or $4 \mathrm{~mm} \mathrm{Hg}$ diastolic blood pressure. Because the two twins in a twin pair were assessed the same day, the adjustment did not influence the results in the intrapair analyses. This was confirmed by analysing both the adjusted and the unadjusted values, which yielded similar results in the analyses of the overall sample as well as the intrapair differences. Birth weight was obtained from the official State of Minnesota birth records. Current weight was measured on a level platform scale with a beam and movable weights.

STATISTICAL ANALYSIS

As in Hopper and Seeman ${ }^{14}$ for each twin, i, of a pair $(i=1,2)$ let $Y_{i}$ be systolic blood pressure and $\mathrm{X}_{1 \mathrm{i}}=$ birth weight and $\mathrm{X}_{2 \mathrm{i}}=$ current weight. Let

$\mathrm{Y}_{\mathrm{i}}=\mathrm{a}_{0}+\mathrm{a}_{1} \mathrm{X}_{1 \mathrm{i}}+\mathrm{a}_{2} \mathrm{X}_{2 \mathrm{i}}+\mathrm{E}_{\mathrm{i}}$

where $E_{i}$ represents measurement error and effects specific to twin $i$. Each of the coefficients $a_{1}$ and $a_{2}$ represents the strength of a linear association between the blood pressure and a corresponding variable. The intrapair difference is

$\mathrm{D}=\mathrm{Y}_{1}-\mathrm{Y}_{2}=\mathrm{a}_{1} \mathrm{D}_{1}+\mathrm{a}_{2} \mathrm{D}_{2}+\mathrm{E}$

where $D_{j}=X_{j 1}-X_{j 2}(j=1,2)$ and $E=E_{1}-E_{2}$. From (2) it can be seen that the same coefficients $a_{1}, a_{2}$ can be estimated by regressing $\mathrm{D}$ against $\mathrm{D}_{1}, \mathrm{D}_{2}$, and constraining the fitted line to pass through the origin (because (2) does not have an intercept term). This second regression approach controls for age, sex and genetic factors (all in monozygotic twins and on average half in dizygotic twins).

\section{Results}

Table 1 shows the expected age and sex patterns for blood pressure: higher values for males than for females and for the older groups compared with the younger groups. There was no systematic difference in blood pressure or birth weight between zygosity groups, but dizygotic twins tended to have the highest current weight.

Table 2 shows the result of the regression analyses. In the overall sample a negative 
Table 2 Difference in systolic pressure ( $\mathrm{mm} \mathrm{Hg}$ ) per $\mathrm{kg}$ increase in birth weight adjusted for current weight. Results for the overall twin sample and for within twin pair (intrapair) comparisons

\begin{tabular}{|c|c|c|c|c|c|c|c|}
\hline & \multirow[b]{2}{*}{ Age } & \multicolumn{2}{|l|}{ Monozygotic twins } & \multicolumn{2}{|l|}{ Dizygotic twins } & \multicolumn{2}{|l|}{ All } \\
\hline & & $\begin{array}{l}\text { Overall sample (SE) } \\
\text { Number }\end{array}$ & $\begin{array}{l}\text { Intrapair comparison } \\
\text { (SE) Number }\end{array}$ & $\begin{array}{l}\text { Overall sample (SE) } \\
\text { Number }\end{array}$ & $\begin{array}{l}\text { Intrapair comparison } \\
\text { (SE) Number }\end{array}$ & $\begin{array}{l}\text { Overall sample (SE) } \\
\text { Number }\end{array}$ & $\begin{array}{l}\text { Intrapair comparison } \\
(S E) \text { Number }\end{array}$ \\
\hline Male & $\begin{array}{l}11-13 \\
17-18\end{array}$ & $\begin{array}{ll}-0.66(1.06) & 498 \\
-1.74(1.39) & 368 \\
-1.38(0.83) & 866\end{array}$ & $\begin{array}{r}1.38(2.64) 249 \\
-2.29(1.87) 184 \\
-0.17(1.66) 433\end{array}$ & $\begin{array}{l}-1.39(1.41) 234 \\
-2.36(1.98) 194 \\
-1.41(1.18) 428\end{array}$ & $\begin{array}{r}0.74(2.83) 117 \\
-0.76(2.88) 97 \\
0.11(2.02) 214\end{array}$ & $\begin{array}{lr}-0.91(0.85) & 732 \\
-1.76(1.16) & 562 \\
-1.40(0.68) 1294\end{array}$ & $\begin{array}{rr}1.19(1.86) & 366 \\
-1.46(1.56) & 281 \\
0.06(1.24) & 647\end{array}$ \\
\hline Female & $\begin{array}{l}11-13 \\
17-18\end{array}$ & $\begin{array}{ll}-4.08(1.56) & 436 \\
-3.45(1.55) & 420 \\
-3.78(1.11) & 856\end{array}$ & $\begin{array}{l}-2.03(2.59) 218 \\
-1.22(1.94) 210 \\
-1.94(1.56) 428\end{array}$ & $\begin{array}{r}-2.55(2.12) 266 \\
1.71(2.03) 206 \\
-0.99(1.45) 472\end{array}$ & $\begin{array}{l}-1.22(2.33) 133 \\
-0.11(3.13) 103 \\
-0.82(1.87) 236\end{array}$ & $\begin{array}{lr}-3.80(1.23) & 702 \\
-1.63(1.24) & 626 \\
-2.85(0.88) & 1328\end{array}$ & $\begin{array}{ll}-1.76(1.68) & 351 \\
-0.73(1.66) & 313 \\
-1.34(1.18) & 664\end{array}$ \\
\hline All & $\begin{array}{l}11-13 \\
17-18\end{array}$ & 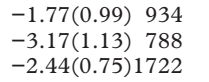 & 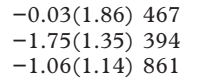 & $\begin{array}{r}-2.36(1.33) 500 \\
2.39(1.69) 400 \\
-0.59(1.07) 900\end{array}$ & $\begin{array}{l}-0.36(1.81) 250 \\
-0.37(2.10) 200 \\
-0.37(1.37) 450\end{array}$ & $\begin{array}{l}-2.06(0.79) 1434 \\
-1.48(0.95) 1188 \\
-1.88(0.61) 2622\end{array}$ & $\begin{array}{ll}-0.23(1.26) & 717 \\
-1.06(1.14) & 594 \\
-0.64(0.86) & 1311\end{array}$ \\
\hline
\end{tabular}

association was found between birth weight and systolic blood pressure: regression coefficient $-1.88 \mathrm{~mm} \mathrm{Hg} / \mathrm{kg}$ (SE 0.61). This value corresponds to those obtained among adolescent singletons. ${ }^{126-8}$ Similar to Taylor et al ${ }^{8}$ we found a larger coefficient for females -2.85 $\mathrm{mm} \mathrm{Hg} / \mathrm{kg}$ (SE 0.88) compared with males $-1.40 \mathrm{~mm} \mathrm{Hg} / \mathrm{kg}$ (SE 0.68). We also found a larger effect for monozygotic twins compared with dizygotic twins, but when the coefficient was stratified according to sex, age and zygosity it was seen that this was primarily attributable to one group (dizygotic women aged 17-18).

If the traditional procedures for calculating the standard errors in the overall analyses are used, then the standard errors will be underestimated because the twins correlate in blood pressure. Therefore we used Generalized Estimating Equations (GEE) ${ }^{15}$ to assess the standard errors in the overall analyses, using the STATA software ${ }^{16}$ (for example, using traditional procedures we obtained a standard error of 0.50 for the regression coefficient for the overall sample $(-1.88 \mathrm{~mm} \mathrm{Hg} / \mathrm{kg})$ compared with the GEE estimate of 0.61).

The intrapair analyses revealed regression coefficient estimates that were closer to zero for both males and females, both sexes showing a reduction of about $1.4 \mathrm{~mm} \mathrm{Hg} / \mathrm{kg}$. The magnitude of reduction was also approximately 1.4 $\mathrm{mm} \mathrm{Hg} / \mathrm{kg}$ when monozygotic twins were considered as a group, while the corresponding number was negligible for dizygotic twins mainly because of the group of women aged 17-18 years.

The appropriateness of controlling for current weight has been questioned, ${ }^{17}$ and we therefore performed the analyses without controlling for current weight (table 3 ). The analyses showed a regression coefficient of $-0.35 \mathrm{~mm} \mathrm{Hg}$ (SE 0.68 ) in the overall sample and $0.60 \mathrm{~mm} \mathrm{Hg}$ (SE 0.86) in the intrapair comparison. Controlling

Table 3 Difference in systolic pressure ( $\mathrm{mm} \mathrm{Hg}$ ) per $\mathrm{kg}$ increase in birth weight (unadjusted). Results for the overall twin sample and for within twin pair (intrapair) comparisons

\begin{tabular}{|c|c|c|c|c|c|c|c|}
\hline & \multirow[b]{2}{*}{ Age } & \multicolumn{2}{|l|}{ Monozygotic twins } & \multicolumn{2}{|l|}{ Dizygotic twins } & \multicolumn{2}{|l|}{ All } \\
\hline & & $\begin{array}{l}\text { Overall sample (SE) } \\
\text { Number }\end{array}$ & $\begin{array}{l}\text { Intrapair comparison } \\
\text { (SE) Number }\end{array}$ & $\begin{array}{l}\text { Overall sample (SE) } \\
\text { Number }\end{array}$ & $\begin{array}{l}\text { Intrapair comparison } \\
\text { (SE) Number }\end{array}$ & $\begin{array}{l}\text { Overall sample (SE) } \\
\text { Number }\end{array}$ & $\begin{array}{l}\text { Intrapair comparison } \\
\text { (SE) Number }\end{array}$ \\
\hline Male & $\begin{array}{l}11-13 \\
17-18\end{array}$ & 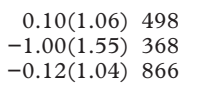 & $\begin{array}{r}3.19(2.39) 249 \\
-0.38(1.83) 184 \\
1.62(1.57) 433\end{array}$ & $\begin{array}{r}-0.60(1.44) 234 \\
-2.28(1.95) 194 \\
1.04(1.44) 428\end{array}$ & $\begin{array}{r}1.44(2.91) 117 \\
-0.62(2.98) 97 \\
0.52(2.09) 214\end{array}$ & $\begin{array}{rr}-0.12(0.86) & 732 \\
-1.21(1.26) & 562 \\
0.37(0.85) & 1294\end{array}$ & 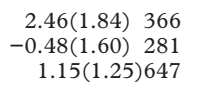 \\
\hline Female & $\begin{array}{l}11-13 \\
17-18\end{array}$ & 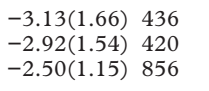 & $\begin{array}{r}-1.32(2.37) 218 \\
0.24(1.97) 210 \\
-0.47(1.53) 428\end{array}$ & $\begin{array}{r}-1.45(2.26) 266 \\
2.91(2.27) 206 \\
-0.31(1.60) 472\end{array}$ & $\begin{array}{r}-0.30(2.36) 133 \\
2.39(3.27) 103 \\
0.70(1.92) 236\end{array}$ & 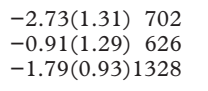 & 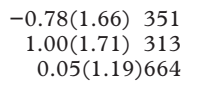 \\
\hline All & $\begin{array}{l}11-13 \\
17-18\end{array}$ & $\begin{array}{lr}-1.06(1.01) & 934 \\
-2.17(1.31) & 788 \\
-1.11(0.84) & 1722\end{array}$ & $\begin{array}{r}1.21(1.69) 467 \\
-0.04(1.36) 394 \\
0.59(1.10) 861\end{array}$ & $\begin{array}{r}-1.54(1.35) 500 \\
4.40(1.94) 400 \\
1.21(1.17) 900\end{array}$ & $\begin{array}{l}0.49(1.84) 250 \\
0.79(2.20) 200 \\
0.62(1.41) 450\end{array}$ & $\begin{array}{l}-1.29(0.80) 1434 \\
-0.07(1.10) 1188 \\
-0.35(0.68) 2622\end{array}$ & $\begin{array}{lr}0.87(1.24) & 717 \\
0.28(1.17) & 594 \\
0.60(0.86) & 1311\end{array}$ \\
\hline
\end{tabular}

Table 4 Difference in systolic pressure ( $\mathrm{mm} \mathrm{Hg}$ ) per kg increase in birth weight adjusted for BMI. Results for the overall twin sample and for within twin pair (intrapair) comparisons

\begin{tabular}{|c|c|c|c|c|c|c|c|}
\hline & \multirow[b]{2}{*}{ Age } & \multicolumn{2}{|l|}{ Monozygotic twins } & \multicolumn{2}{|l|}{ Dizygotic twins } & \multicolumn{2}{|l|}{ All } \\
\hline & & $\begin{array}{l}\text { Overall sample (SE) } \\
\text { Number }\end{array}$ & $\begin{array}{l}\text { Intrapair comparison } \\
(S E) \text { Number }\end{array}$ & $\begin{array}{l}\text { Overall sample (SE) } \\
\text { Number }\end{array}$ & $\begin{array}{l}\text { Intrapair comparison } \\
(S E) \text { Number }\end{array}$ & $\begin{array}{l}\text { Overall sample (SE) } \\
\text { Number }\end{array}$ & $\begin{array}{l}\text { Intrapair comparison } \\
(S E) \text { Number }\end{array}$ \\
\hline Male & $\begin{array}{l}11-13 \\
17-18\end{array}$ & $\begin{array}{ll}-0.16(1.05) & 498 \\
-1.19(1.39) & 368 \\
-0.70(0.89) & 866\end{array}$ & $\begin{array}{r}1.65(2.55) 249 \\
-1.16(1.80) 184 \\
0.40(1.60) 433\end{array}$ & $\begin{array}{l}-1.08(1.38) 234 \\
-2.15(2.01) 192 \\
-0.25(1.26) 426\end{array}$ & $\begin{array}{l}0.82(2.84) 117 \\
0.54(2.89) 96 \\
0.68(2.01) 213\end{array}$ & $\begin{array}{lr}-0.46(0.84) & 732 \\
-1.38(1.17) & 560 \\
-0.57(0.73) & 1292\end{array}$ & $\begin{array}{rr}1.37(1.85) & 366 \\
-0.42(1.54) & 280 \\
0.57(1.23) 646\end{array}$ \\
\hline Female & $\begin{array}{l}11-13 \\
17-18\end{array}$ & $\begin{array}{ll}-3.48(1.58) & 436 \\
-3.19(1.50) & 420 \\
-3.19(1.09) & 856\end{array}$ & $\begin{array}{l}-2.25(2.55) 218 \\
-0.33(1.90) 210 \\
-1.56(1.53) 428\end{array}$ & $\begin{array}{r}-1.76(2.13) 266 \\
2.16(2.04) 206 \\
-0.57(1.46) 472\end{array}$ & $\begin{array}{r}-0.79(2.30) 133 \\
0.77(3.09) 103 \\
-0.20(1.84) 236\end{array}$ & $\begin{array}{lr}-3.12(1.25) & 702 \\
-1.31(1.21) & 626 \\
-2.32(0.87) & 1328\end{array}$ & $\begin{array}{rr}-1.59(1.66) & 351 \\
0.07(1.63) & 313 \\
-0.87(1.17) 664\end{array}$ \\
\hline All & $\begin{array}{l}11-13 \\
17-18\end{array}$ & $\begin{array}{lr}-1.30(0.98) & 934 \\
-2.42(1.24) & 788 \\
-1.69(0.78) & 1722\end{array}$ & $\begin{array}{l}-0.02(1.81) 467 \\
-0.74(1.32) 394 \\
-0.56(1.11) 861\end{array}$ & $\begin{array}{r}-1.91(1.31) 500 \\
4.05(1.87) 398 \\
0.53(1.11) 898\end{array}$ & $\begin{array}{r}-0.05(1.80) 250 \\
0.59(2.08) 199 \\
0.19(1.36) 449\end{array}$ & $\begin{array}{l}-1.60(0.78) 1434 \\
-0.39(1.04) 1186 \\
-1.00(0.64) 2620\end{array}$ & $\begin{array}{lr}-0.05(1.25) & 717 \\
-0.16(1.12) & 593 \\
-0.15(0.85) 1310^{\star}\end{array}$ \\
\hline
\end{tabular}

${ }^{\star}$ Missing values for height in one twin pair. 
for current BMI index instead of current weight resulted in a regression coefficient of $-1.00 \mathrm{~mm}$ $\mathrm{Hg}$ (SE 0.64) in the overall sample and -0.15 $\mathrm{mm} \mathrm{Hg}(\mathrm{SE} 0.85)$ in the intrapair analyses (table 4). Common to the subanalyses is the attenuation of the negative correlation between birth weight and blood pressure when the analyses are performed within pairs.

\section{Discussion}

Among the many phenotypes considered in the fetal programming hypothesis, blood pressure is the one that most consistently has been shown to be associated with birth weight. The size of the association is modest: from a reduction of $1-2 \mathrm{~mm} \mathrm{Hg} / \mathrm{kg}$ increase in birth weight for children to $5 \mathrm{mmHg} / \mathrm{kg}$ among elderly people. ${ }^{16}$ For adolescents only few and small studies had been published until recently, but new studies on more than 14900018 year old Swedes and 3000 8-11 year old British children have shown associations similar to those obtained in studies of younger children, although with sex differences. ${ }^{78}$

In our sample of adolescent twins we also found a negative association between birth weight and systolic blood pressure and it was confirmed that the association is stronger among girls. The association was reduced when we used intrapair twin comparisons, which controlled for genetic factors as well as factors associated with the mother's socioeconomic status. However, it has been argued that confounding by socioeconomic status is negligible. ${ }^{13}$

The most interesting subgroup for the intrapair analyses was the monozygotic pairs, because monozygosity allows all genetic factors to be controlled for. In accordance with the hypothesis about genetic factors influencing both fetal growth and later life blood pressure, we found that the regression coefficient estimate attenuated compared with the overall analyses. The findings in the dizygotic group were less consistent, maybe not only because of the lower level of genetic control but maybe also because of chance findings attributable to the smaller sample size compared with the monozygotic group.

The twin design used here has several advantages. Not only is it possible to control for genetic factors and maternal socioeconomic status, but because the twins are born at the same time the intrapair comparisons also control for gestational age. A concern could be that the birth weight differences in twins are unrelated to programming and that among monozygotic pairs twin to twin transfusion could play a part. However, Phillips ${ }^{12}$ has argued that in twins even small weight differences could have a major "programming effect" because twins are already small for date. Another concern could be that a study from New Zealand found evidence that twins have lower blood pressure than singletons when numerous factors were controlled for. ${ }^{18}$ However, our finding in the overall twin sample of a negative association between birth weight and systolic blood pressure - of the same magnitude as seen in studies of singletons - suggests
KEY POINTS

- The association between low birth weight and increased blood pressure later in life is well established.

- "The fetal programming hypothesis" suggests that the association is caused by intrauterine malnutrition.

- "The fetal insulin hypothesis" proposes that genetically determined insulin resistance contribute to the association between fetal growth and later life health.

- This twin study showed that the association between birth weight and systolic blood pressure attenuated when intrapair comparisons were made.

- Our twin data suggest that genetic factors contribute to the association between fetal growth and systolic blood pressure in adolescence.

that the twin sample is well suited for testing the fetal-insulin hypothesis.

While our findings are similar to a new study of 114 adolecent twin pairs, ${ }^{19}$ they differ considerably from the recent twin studies by Poulter et $a l^{9}$ and Dwyer et $a l^{10}$ of 492 pairs of middle aged female twins and 52 pairs aged 8, respectively. Both these studies found a large birth weight effect within twin pairs ( $>5 \mathrm{~mm}$ $\mathrm{Hg} / \mathrm{kg}$ ) and no attenuation when genetic factors were controlled for. Our study includes more than three times the total number of monozygotic twin pairs in these two studies, and especially the study of 8 year olds was based on a very small sample, so this may well be a chance finding. It may be the case that genetic factors play a part for the association between birth weight and blood pressure in adolescence, but not in mid-life. That is, the correlation between birth weight and blood pressure may have different background at different ages.

Based on the fetal programming hypothesis, public health messages are currently sent out about the influence of fetal nutrition on the health of newborns throughout life. ${ }^{20}$ These messages may create concerns among pregnant women regarding their dietary habits before and during pregnancy. From a public health perspective this is excellent if the concerns are appropriate and result in healthier mothers and babies. On the other hand, concerns should not be introduced among millions of women without strong evidence. The fetal programming hypothesis suggests that it is fetal nourishment that causes the link between fetal growth and later life health. Our study supports the fetal insulin hypothesis that suggests that genes may contribute to the negative association between fetal growth and later life systolic blood pressure. The direct evidence provided by Dunger et $a l^{4}$ of a genetic factor (the insulin gene) that affects both fetal growth and later life health also points toward a genetic component in the association. Studies of intrapair differences in twins and siblings at various ages are two promising research areas for assessing 
the magnitude of genetic confounding in the association between fetal growth and later life health.

Funding: the activities of the Danish Center for Demographic Research are funded by a grant from the Danish National Research Foundation. The Minnesota Twin Family Study is supported by United States Public Health Service Grants DAO1957 and AA. K Christensen is supported by the US National Institutes of Health (grant AG08761).

Conflicts of interest: none.

1 Barker DJP. Mothers, babies and health in later life. Edinburgh: Churchill Livingstone, 1998.

2 Kuh D, Ben-Shlomo YA. Life course approach to chronic disease epidemiology. Tracing the origins of ill-health from early to adult life. Oxford: Oxford University Press, 1997.

3 Leon DA, Lithell HO, Vagero D, et al. Reduced fetal growth rate and increased risk of death from ischaemic heart rate and increased risk of death from ischaemic heart disease: cohort study of 15000 Swedist 4 Dunger DB, Ong KK, Huxtable SJ, et al. Association of the INS VNTR with size at birth. ALSPAC Study Team. Avon
Longitudinal Study of Pregnancy and Childhood. Nat

5 Hattersley AT, Tooke JE. The fetal insulin hypothesis: an alternative explanation of the association of low birthweight with diabetes and vascular disease. Lancet 1999;353:178992.

6 Law CM, Shiell AW. Is blood pressure inversely related to birth weight? The strength of evidence from a systematic review of the literature. F Hypertens 1996;14:935-41.

7 Nilsson PM, Ostergren PO, Nyberg P, et al. Low birth weight is associated with elevated systolic blood pressure in adolescence: a prospective study of a birth cohort of 149378 Swedish boys. F Hypertens 1997;15:1627-31.

8 Taylor SJ, Whincup PH, Cook DG, et al. Size at birth and blood pressure: cross sectional study in 8-11 year old children. BMF 1997;314:475-80

9 Poulter NR, Chang CL, MacGregor AJ, et al. Association between birth weight and adult blood pressure in twins: historical cohort study. BMF 1999;319:1330-3.

10 Dwyer T, Blizzard L, Morley R, et al. Within pair association between birth weight and blood pressure at age 8 in twins from a cohort study. BMF 1999;319:1325-9.

11 Leon DA. Twins and fetal programming of blood pressure. BMF 1999;319:1313-14.

12 Phillips DI. Twin studies in medical research: can they tell us whether diseases are genetically determined? Lancet 1993:341:1008-9.

13 Iacono WG, Carlson SR, Taylor J, et al. Behavioral disinhibition and the development of substance use disorders: Findings from the Minnesota Twin Family Study. Dev Psychopathol 1999;11:869-900.

14 Hopper JL, Seeman E. The bone density of female twins discordant for tobacco use. N Engl f Med. 1994;330:38792.

15 Armitage P, Colton T, eds. Encyclopedia of biostatistics. Vol 2. Chichester: John Wiley, 1998:1626-37.

16 StataCorp. Stata statistical software: release 6.0. College Station, TX: Stata Corporation, 1999.

17 Lucas A, Fewtrell MS, Cole TJ. Fetal origins of adult disease - the hypothesis revisited. BMF 1999;319:245-9.

18 Williams S, Poulton R. Twins and maternal smoking: ordeals for the fetal origins hypothesis? A cohort study. BMF 1999;318:897-900.

19 Ijzerman RG, Stehouwer CDA, Boosma DI. Evidence for genetic factors explaining the birthweight-blood pressure relation. Hypertension 2000;36:10008-12.

20 Begley S. Shaped by life in the womb. Newsweek 1999;50-7.

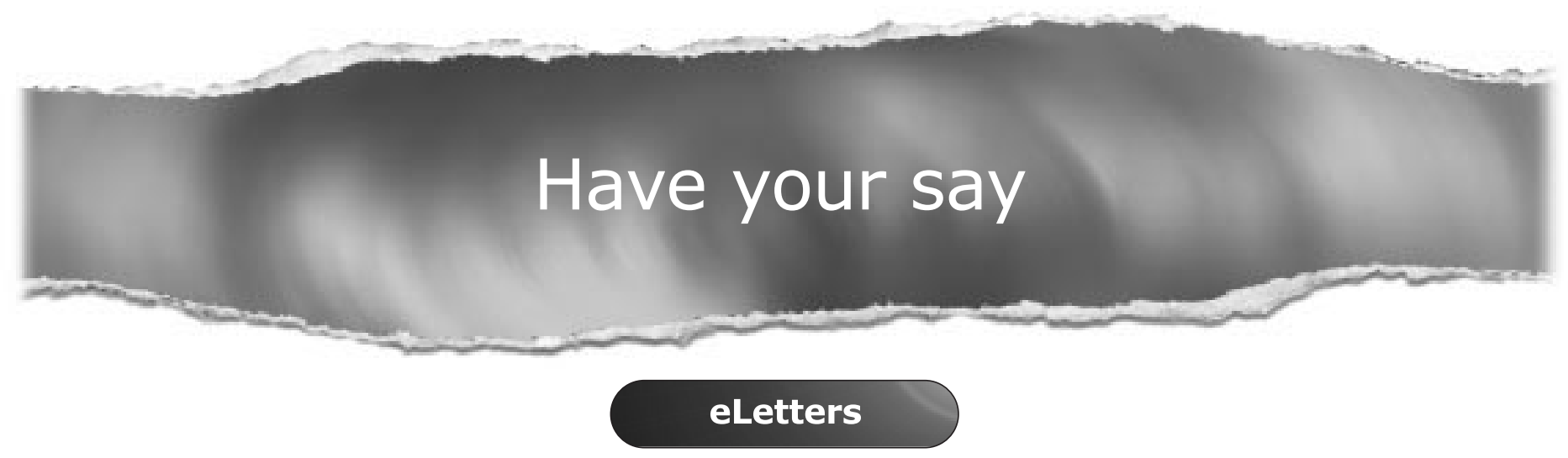

If you wish to comment on any article published in the Journal of Epidemiology and Community Health you can send an eLetter using the eLetters link at the beginning of each article. Your response will be posted on Journal of Epidemiology and Community Health online within a few days of receipt (subject to editorial screening).

www.jech.com 